\title{
UDC 004.77
}

\section{METHOD OF DEVELOPMENT AND ARCHITECTURE OF INTEGRATIVE ONTOORIENTED SYSTEM FOR PROFFESIONAL HEALING ACTIVITY «IMAGE THERAPIST» FOR THE CHINESE IMAGE MEDICINE}

\author{
Oleksandra Orobchuk ${ }^{1}$; Ihor Kateryniuk ${ }^{2}$
}

\author{
${ }^{I}$ Ternopil Ivan Puluj National Technical University, Ternopil, Ukraine \\ ${ }^{2}$ Inlimited, Kyiv, Ukraine
}

\begin{abstract}
Summary. The article is devoted to substantiation of urgency of development, as well as the statement of general requirements, development of architecture and prototype of integrative onotoriented system of professional healing "Image Therapist» for Chinese Image Medicine as a promising component of Integrative medicine, diagnostics and therapeutic ontology as the core knowledge of this subject area were developed.

Key words: ontology, ontological modeling, Chinese Image Medicine, integrative informational and analytical environment, system of professional healing «Image Therapist».
\end{abstract}

Statement of the problem. Nowadays the conditions, in which modern west medicine happened to be, facilitate the development of Integrative medicine, which in its diagnostics and therapeutic methods combines the technologies and methods of modern west medicine and alternative healing medical experience. Sufficient component of the Integrative medicine is the traditional Chinese medicine (TCM), the methods of which are widely used in the world. More than 80 agreements on medical and pharmaceutical cooperation were signed, more than 10 foreign Centers and hundreds of educational institutions were set up. Lately the interest in the ancient TCM component, Chinese Image Medicine (CIM), possessing the exclusive set of diagnostics methods and treating the patient on all its fundamental ontological levels has raised greatly: physical, energetic, informational and spiritual-mental. For the practical application of the CIM methods in conventional medicine theoretical scientific substantiation and some clinical investigations must be carried out at the scientific level and some informational and analytical means, which are not available now must be developed. With this purpose the Program for the scientific investigations of the Chinese Image Medicine for 2017-2023 years [1] has been developed at the CIM world Center of education and investigation - the Pekin medical investigation institute «Kundawell». Besides, according to the WHO strategy in the field of healing [2] and the regulations of the Ministry of Health Care of Ukraine [3] these investigations are needed for the CIM to be included in the integrative medicine as scientifically grounded branch of medicine.

Analysis of the results of investigation. The first steps in solving this unusual scientific task were presented in the papers [4-13]. Having analyzed them [4-7], it was revealed that the ontology and ontooriented information systems are presented for the traditional Chinese medicine (TCM). It is caused by the fact, that in China TCM and west medicine are known to be mutually benefitual enriching each other in understanding the body itself and processes 
taking part in it and the thickness etymology. Thus, the medical ontological system UTCMLC has been developed - the only traditional Chinese system of medical language, which contains the statements of medical concepts with the corresponding TCM scale of terminological sources [6-7]. Lately UTCMLS has been improving using the Protégé 2000 environment. Basing on it some other clinical terminological systems were built, e. g. ICD-10, SNOMED-CT, TradiMed, TCM-ID, etc. At the same time, it was revealed, that similar informational systems for CIM are not available. That is why in paper [8] the need to create the integrative ontooriented informational-analytical environment for the scientific investigations and professional healing CIM electronic learning was interpreted. The main requirements have been stated and general architecture of the environment components has been developed. These components are: "Image Therapist", CIM database, expert system for supporting the diagnostic and therapeutic solutions, informational system of CIM electronic learning, informational system of CIM scientific investigations. In the paper [9] the main stages of creation the CIM scientific paradigm and designing of integrative environment, have been developed, where the key problem is that of development of the CIM computer ontology, its structure being presented in details. The CIM ontology will solve some important problems of theoretical, clinical, experimental, as well as the informational-analytical spheres of the Program of scientific investigations. The paper [10] is devoted to the critically important stage of the mentioned above task - the testing of the CIM expert's knowledge, on the performance of which the ontology quality and future software systems depend. To build the CIM scientific theory and ontology the knowledge of Chinese healers obtained during centuries must be accessible and then ontologically systematized, which will make possible to unify the CIM terminology and to internationalize it, transforming this knowledge for the application in the informational systems. In the paper [11] the methods and tools of the CIM semantic space were determined, the axiom - deduction strategy of the knowledge organization in the informational system of the CIM electronic learning were presented, which will make possible to apply modern tools for the collective development of the electronic courses learning not only for CIM, but for other areas of the Integrative medicine. The papers $[12,13]$ are devoted to the realization of the integrative environment components - the informational system of the CIM electronic learning (ISEL CIM). The importance and prospects for the ISEL CIM development using the ontology of the CIM subject and modern system of control of the educational activity, which will provide the efficient control and spreading of educational on-line materials providing mutual access to them. This approach is reasonable enough and promising for CIM, as the efficient ways of providing the educational material for those interested in CIM are not available. To solve the problems of clinical investigations of diagnostics and therapy using the CIM methods successfully the integrative ontooriented system of professional healing activity «Image Therapist» is to be developed. As the investigations and design-technological solutions for the architecture and the stages of development of such system are not available, it caused this article to be presented.

The Objective. To develop the method of creation, architecture and the prototype of the integrative ontooriented system for professional healing activity «Image Therapist».

Statement of the task. To reach the goal it is necessary to investigate the advantages of the ontologies application as the main component of the informational systems, to analyze the stages of the ontooriented systems development, to design the prototypes of integrative ontooriented system of the professional healing activity «Image Therapist».

Results of investigations. Both the west (conventional) medicine and healing 
(nonconventional) medicines have common objective - to make the progress in medicine. The CIM internationalization cannot be successful because of its poor structuralization and terminology being polysemantic, as well as the unified standards of treatment are not available, the treatment effect mechanism being not clear enough. Now it is high time to come from accumulating of experience to the innovation scientific clinical investigations in the CIM sphere. It will make possible to state the standards system and to testify the treatment efficiency and control of the quality and safety of the CIM methods after its being on the world market. That is why the system-forming and technological basis of the informational system of the professional healing «Image Therapist» must be diagnostics (Figure 1) and therapeutic (Figure 2). CIM ontologies, while developing of which the stages of the IDEF5 methodology [14] were followed and highly-qualified CIM experts were engaged. It made possible to build the base of the declare knowledge, to formalize the terms and their logical interrelation, to provide interoperation.

The tasks which solve the development of ontooriented system of the professional healing «Image Therapist» are: creation of the unified database and the knowledge base for the clinical CIM investigations; efficiency improvement (demonstration, efficiency, reliability, economic effectiveness) of the professional activity of the CIM therapists; exchange of experience between the CIM therapists as well as efficient organization and coordination of their operation; providing high scientific, technological and infrastructural levels of obtaining them, automatic statistical and intellectual analysis of the results of diagnostics and treatment of the SIM methods; creation of modern intellectualized informational resources in the SIM sphere and Integrated medicine.
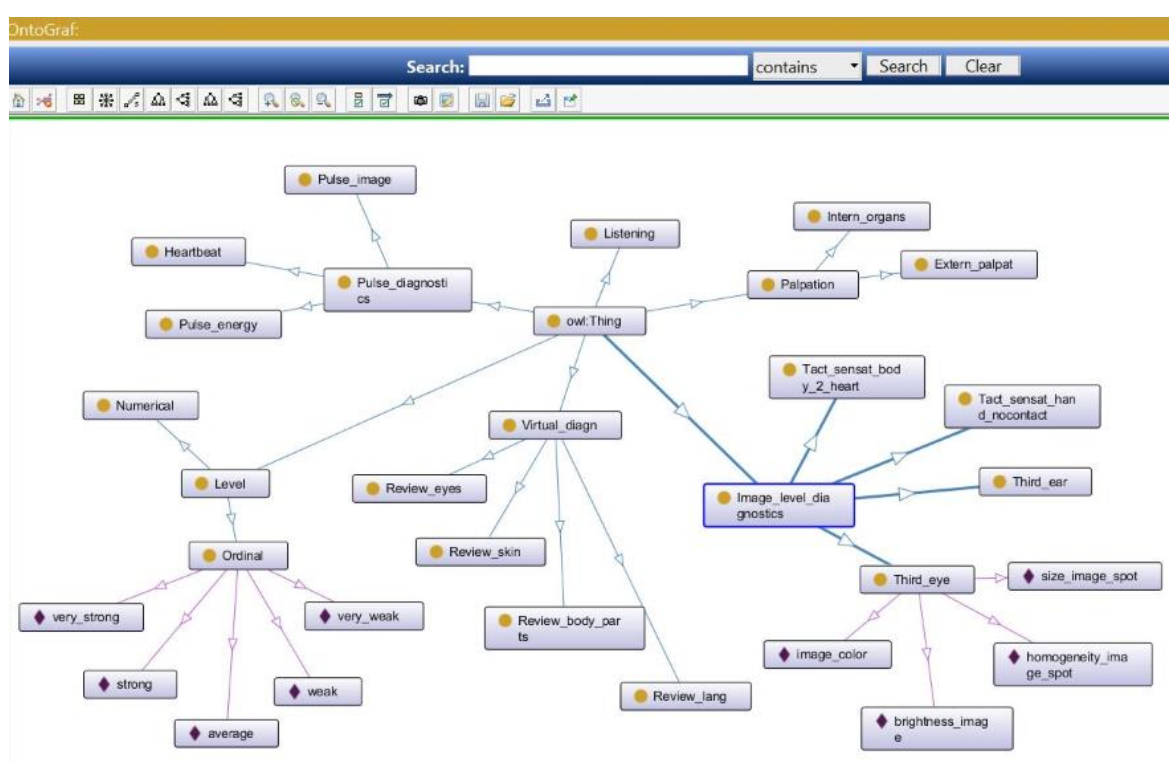

Figure 1. Ontograph of diagnostic CIM ontology 


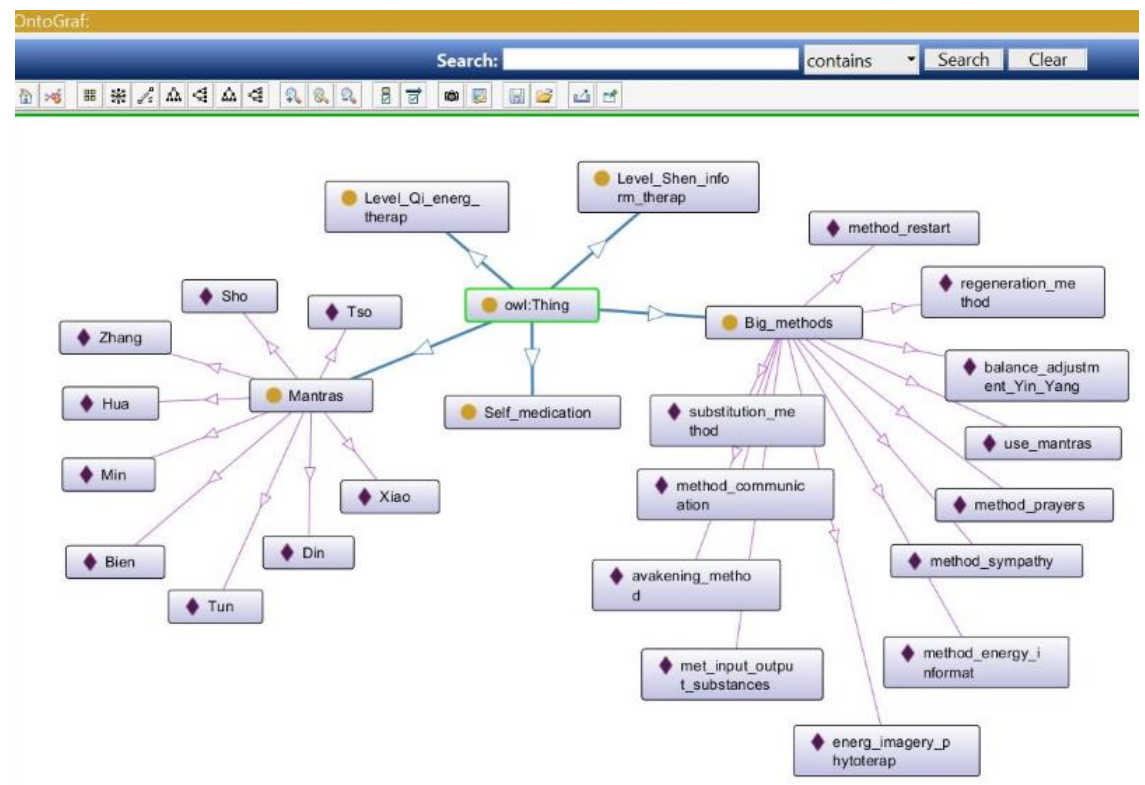

Figure 2. Ontograph of therapeutic CIM ontology

Let us state the functional requirements to the ontooriented system of the professional healing «Image Therapist»:

- the system must interact with the other components of the integrative ontooriented informational-analytical environment of the scientific investigations professional healing and electronic CIM learning;

- the system as the core of knowledge must use the diagnostic and therapeutic CIM ontology;

- the possibility for the patient to be registered must be realized in the system as well as his personal data, his diagnosis in the west nothology in particular;

- the possibility for fixing the factors on the level of his sickness obtained by the CIM-diagnostics methods must be realized;

- the possibility of therapeutic sessions fixing must be realized in the system.

According to the functional requirements the general architecture of the system «Image Therapist» was developed.

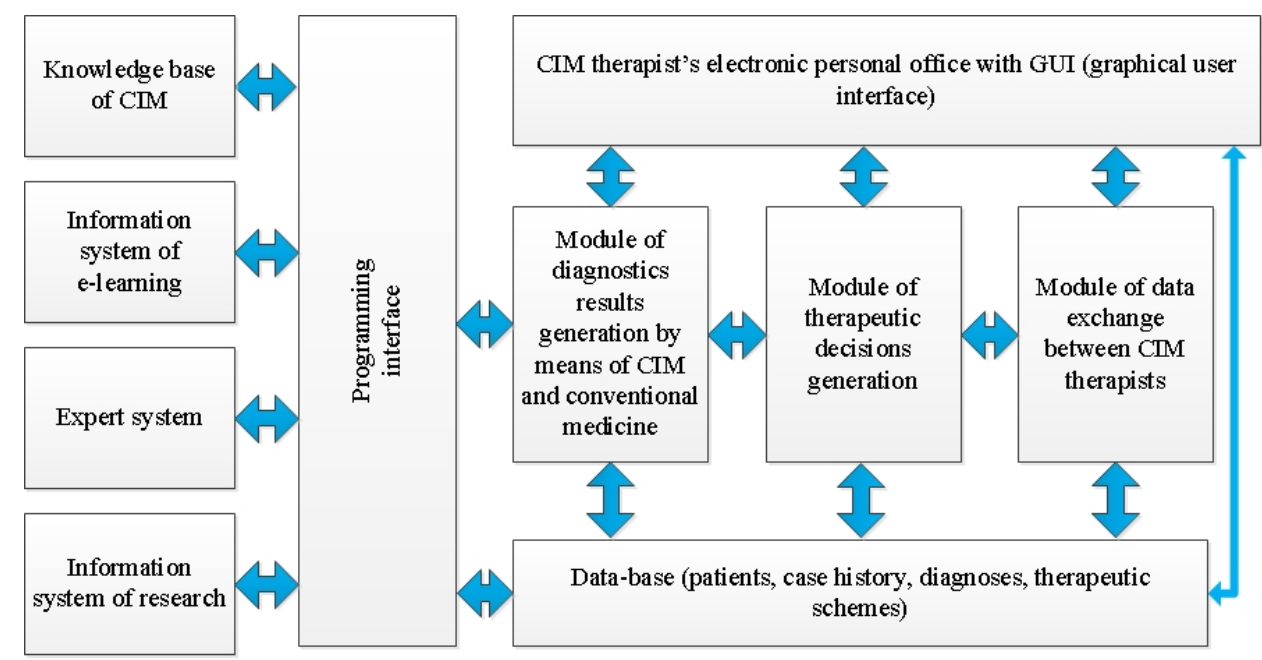

Figure 3. General architecture of information ontobased system of professional healing «Image Therapist» 
The nature of the diagnostic methods and diagnostic information in CIM being nonstandard and unusual for the west medicine, it is worth paying special attention to the creation of new models, methods and means of presenting diagnostic information, the CIM image information in particular, which are the functional requirements to the system. First of all, it is the need to develop the interactive informational subsystem to present the image diagnostic information. The main approach to the development of such system is based on the image model of the human body and its parts, including physical, energetic and informational aspects. That is, this model must include the scale of ranks of the human body parts (areas), the body parts, organ systems, separate organs and organ parts, the set of $R$ relations between the layout elements, reflecting the pathological interrelations identified by the CIM specialist, as well as the attribute sets, which specify every element of the layout and every element of the relation (physical, energetic, informational levels of sickness, the degree of sickness reveal, additional data).

The module for forming the diagnostics results using CIM methods must provide the input of the personal and medical information of patients, which include the information obtained by the methods of conventional medicine, that is, history of sickness and the results of medical investigations (laboratory analysis, results of functional diagnostics, doctor's inference, etc.) as well as the diagnostic information obtained by the TCM and CIM methods, that is, the results of manual therapy diagnostics, energetic manual diagnostics, the results of internal image diagnostics (the «brain eye», «second heart») and self-estimation information (physical and psychological state) of the patient before and after the therapy.

Table 1

Types of diagnostic information in system «Image Therapist»

\begin{tabular}{|l|l|}
\hline $\begin{array}{l}\text { Personal information } \\
\text { (age, sex, family members, } \\
\text { etc) }\end{array}$ & $\begin{array}{l}\text { Medical information about the patient includes that obtained } \\
\text { by the methods of conventional medicine, that is, history of } \\
\text { sickness and results of medical investigations (laboratory } \\
\text { analysis, results of functional diagnostics, doctor's inference, } \\
\text { etc.) }\end{array}$ \\
\hline $\begin{array}{l}\text { Self-estimation } \\
\text { information (physical and } \\
\text { psychological state of the } \\
\text { patient before and after the } \\
\text { therapy using the methods } \\
\text { of psychological scaling) }\end{array}$ & $\begin{array}{l}\text { Diagnostic information obtained by the TCM and CIM } \\
\text { methods, that is, results of diagnostics by the CIM methods } \\
\text { (checkup, patient's complaints, results of manual } \\
\text { diagnostics), results of energetic manual diagnostics, results } \\
\text { of internal image diagnostics (The «brain eye», «second } \\
\text { heart») }\end{array}$ \\
\hline
\end{tabular}

The elements (terms) of the system must be used as the definite examples of classes of the CIM diagnostic and therapeutic ontology as well as the attributes sets, which specify every element (the degree of sickness reveal in some measuring scales and additional data), thus being the components of the ontooriented the CIM knowledge base. 
Table 2

Components of the diagnostic CIM ontology

\begin{tabular}{|c|l|}
\hline $\begin{array}{c}\text { Components of the } \\
\text { diagnostic CIM } \\
\text { ontology }\end{array}$ & \multicolumn{1}{|c|}{ Description of the diagnostic CIM ontology } \\
\hline $\begin{array}{c}\text { Nothology CIM } \\
\text { ontology }\end{array}$ & $\begin{array}{l}\text { Represents the knowledge on types (classes) of sickness taken in the } \\
\text { theory of the CIM diagnostics. }\end{array}$ \\
\hline $\begin{array}{c}\text { Topological } \\
\text { diagnostic CIM } \\
\text { ontology }\end{array}$ & $\begin{array}{l}\text { Represents data on the topological localization of thickness on the } \\
\text { physical body, energetic system (system Chi) and informational } \\
\text { systems (psycho-spiritual systems, system Shen), information on the } \\
\text { body parts, organs, physical body tissues, bioactive points and } \\
\text { energetic channels of energetic system of humans psycho-emotional } \\
\text { mental and spiritual topological aspects of the person. }\end{array}$ \\
\hline $\begin{array}{c}\text { Ontology of } \\
\text { diagnostic CIM } \\
\text { methods }\end{array}$ & $\begin{array}{l}\text { Represents the knowledge of the methods (channels) of obtaining and } \\
\text { specification of the sensor diagnostic information in CIM. }\end{array}$ \\
\hline $\begin{array}{c}\text { Ontology of } \\
\text { diagnostic CIM } \\
\text { measurement }\end{array}$ & $\begin{array}{l}\text { Describes the quantitive characteristics (data) of the diagnostic CIM } \\
\text { space, which determine the degree of manifestation of the certain } \\
\text { sickness and can be presented by means of numerical and non- } \\
\text { numerical scaling. }\end{array}$ \\
\hline
\end{tabular}

For the software realization of the system «Image Therapist» some modern means of web-development were chosen:

- Laravel 6 - free PHP framework with the open code designed for the webdevelopers. Advantages: convenient wide functional (does not need additional installations) simple syntax.

- MySQL 5.8 - free system of database control with the open code.

- Bootstrap 3 - free HTML, CSS and JavaScript framework with the open code for the development of the interface components and web-pages interactivity providing crossbrowsing and adaptivity.

In Figure 4 the ER-diagram of the system «Image Therapist» database is presented, where its main objects are specified and connected between each other by the Tables. In Figure 5-7 the appearance of windows of the developed prototype of the system «Image Therapist» is presented.

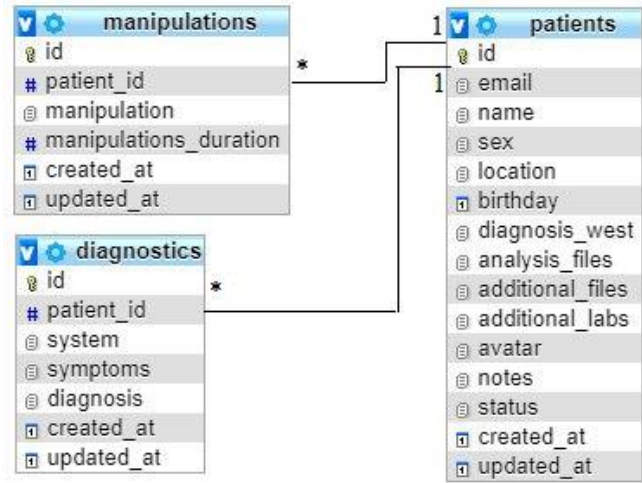

Figure 4. ER-diagram of the System «Image Therapist» Database

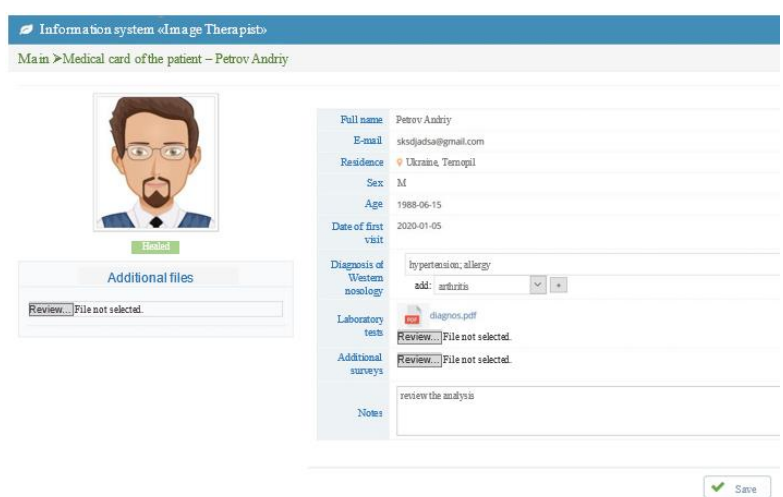

Figure 5. Patient card of the System «Image Therapist» 


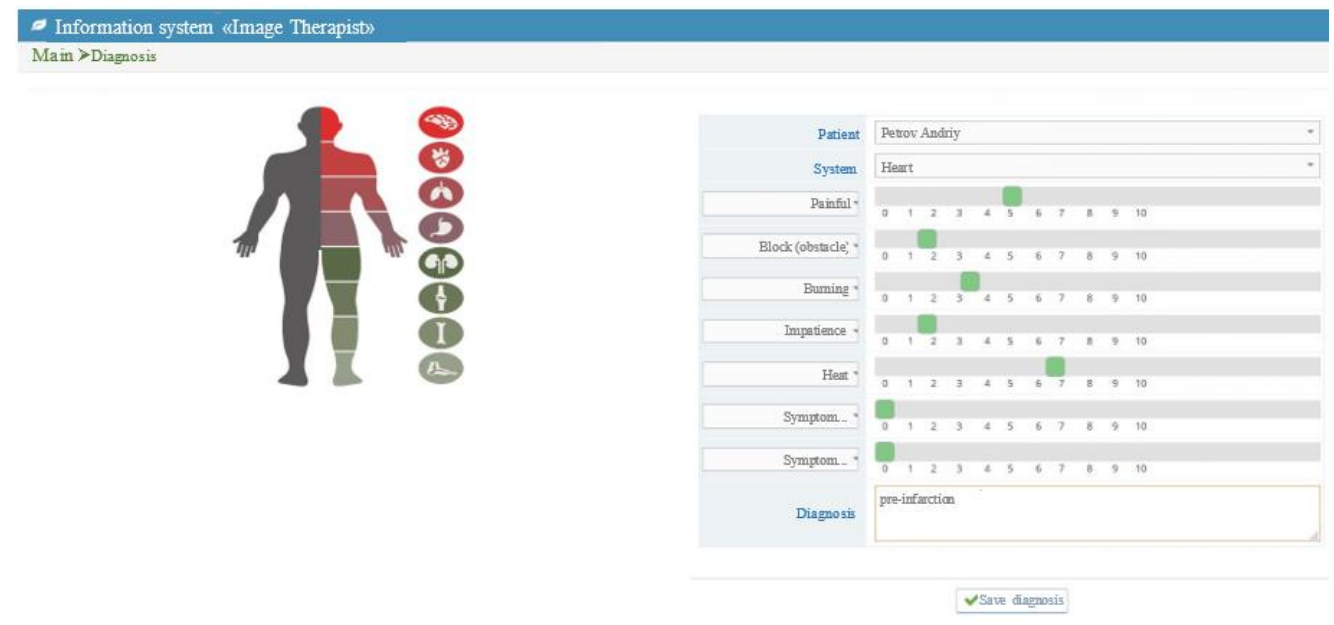

Figure 6. Window with diagnostic information

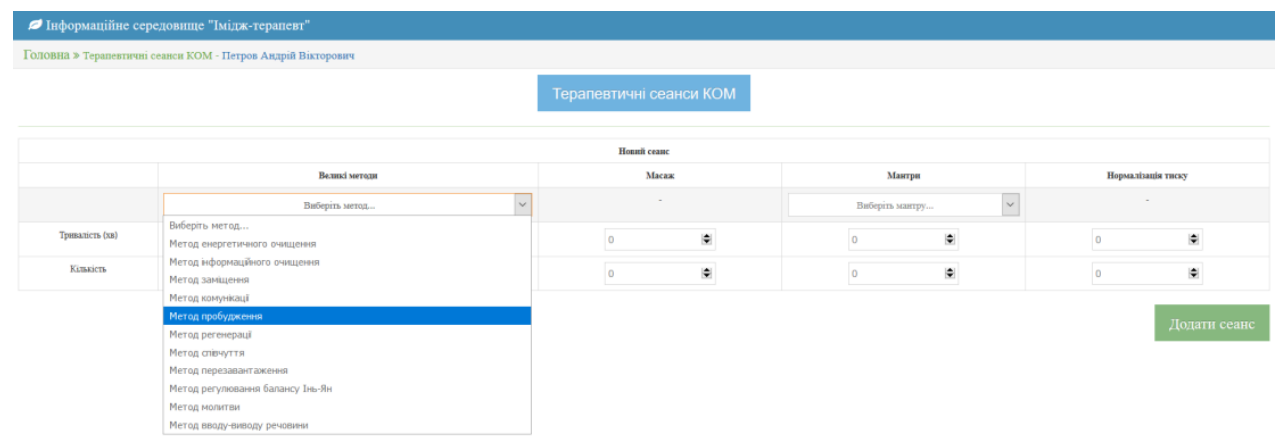

Figure 7. Window of therapeutic sessions

Conclusions. In the paper the method of development and architecture of the integrative ontooriented system of professional healing activity «Image Therapist» was proposed. Its personalized prototype was designed. The ontoorientation of this system can solve the problem of complete presentation and logical agreement of CIM. The presented method of development and the system architecture is universal and can be used in the further investigations. They include development of the experts system of support and solution-making of diagnostics and therapeutic decisions in the CIM sphere, the further clinical verification of the diagnostic and therapeutic CIM methods, complete realization the Program for scientific investigations of CIM and ZYQ, development of the scientific CIM theory and Integrative medicine while engaging in it the other types of healing, for which the corresponding ontologies are developed and which are to be included into the Integrative medicine as the scientifically grounded methods of treatment.

\section{References}

1. International program of scientific research in Chinese image medicine and Zhong Yuan Qigong for 20172023. URL: https://kundawell.com/ru/mezhdunarodnaya-programma-nauchnykh-issledovanij-kitajskojimidzh-meditsiny-i-chzhun-yuan-tsigun-na-2017-2023-god, free access (date of access: 10.01.2020).

2. WHO strategy for traditional medicine for 2014-2023. 2013. 72 p. URL: http://www.who.int/medicines/ publications/traditional/trm_strategy14_23/ru/, free access (date of access: 10.01.2020). 
3. Xie X. GaoThe idea and approach of the mutual complementarity and integration of TCM and western medicine J Chendu College TCM. 17 (2). 1994. P. 14-17. [In Chinese].

4. Chen K., Lu A., Chen S., Wei B., Lu W., Mu D., et al. Survey on the developing status of integrative Chinese and western medicine Zhongguo zhong xi yi jie he za zhi. 26 (6). 2006. P. 485-488. [In Chinese].

5. Mao Y, Wu Z, Chen H, Xu Z. Context-based web ontology service for TCM information sharing. In: Proceedings of IEEE international conference on web services. ICWS'05. 2005. P. 699-705.

6. Chen H., Mao Y., Zheng X., Cui M., Feng Y., Deng S., et al. Towards semantic e-Science for traditional Chinese medicine. BMC Bioinform. 8. Suppl. 3. 2007. P. 56. https://doi.org/10.1186/1471-2105-8-S3-S6

7. Оробчук О. Р., Лупенко С. А., Вакуленко Д. В., Сверстюк А. С., Горкуненко А. Б. Integrated Ontobased Information Analytical Environment of Scientific Research, Professional Healing and E-learning of Chinese Image Medicine. Вісник «Інформаційні системи та мережі». Львів: Національний університет «Львівська політехніка», 2017. С. 10-19.

8. Lupenko S., Orobchuk O., Xu M. The Ontology as the Core of Integrated Information Environment of Chinese Image Medicine / eds Hu Z., Petoukhov S., Dychka I., He M. Advances in Computer Science for Engineering and Education II. ICCSEEA 2019. Advances in Intelligent Systems and Computing. Vol 938. 2020. Springer, Cham. P. 471-481. https://doi.org/10.1007/978-3-030-16621-2_44

9. Lupenko S., Orobchuk O., Osukhivska H., Xu M., Pomazkina T. Methods and means of knowledge elicitation in Chinese Image Medicine for achieving the tasks of its ontological modeling: conference proceedings: Ieee 2nd Ukraine Conference on Electrical and Computer Engineering (Lviv, July 2-6, 2019.). Lviv, 2019. P. 885-858. (IEEE UKRCON-2019). https://doi.org/10.1109/UKRCON.2019.8879851

10. Lupenko S., Pasichnyk V., Kunanets N., Orobchuk O., Mingtang Xu. The Axiomatic-Deductive Strategy of Knowledge Organization in Onto-based e-learning Systems for Chinese Image Medicine. Informatics \& Data-Driven Medicine. Proceedings of the 1st International Workshop on Informatics \& Data-Driven Medicine. November 2018. Vol. 2255. P. 126-134.

11. Lupenko S., Orobchuk O., Pomazkina T., Mingtang X. Conceptual, Formal and Software-Information Fundamentals of Ontological Modeling of Chinese Image Medicine as an Element of Integrative Medicine. World Science. June 2018. Vol. 1. № 6 (34). DOI: https://doi.org/10.31435/rsglobal_ws.

12. Orobchuk O. Methodology of development and architecture of ontooriented system of electronic learning of Chinese image medicine on the basis of training management system. Scientific Journal of TNTU 2018. Vol. 92. No. 4. P. 83-90. https://doi.org/10.33108/visnyk_tntu2018.04.083

13. URL: http://www.idef.com/idef5-ontology-description-capture-method (date of access: 11.01.2020).

14. Palagin A. V. Architecture of ontology-controlled computer systems. Cybernetics and system analysis. 2006. No. 2. P. 111-124. https://doi.org/10.1007/s10559-006-0061-z

15. "Committee on Folk and Alternative Medicine of the Ministry of Health of Ukraine". URL: http://moz.gov.ua/ ua/portal/oth_narmed.html, free (date of access: 12.01.2020).

\section{Список використаної літератури}

1. Международная программа научных исследований китайской имидж-медицины и Чжун Юань цигун на 2017-2023. URL: https://kundawell.com/ru/mezhdunarodnaya-programma-nauchnykhissledovanij-kitajskoj-imidzh-meditsiny-i-chzhun-yuan-tsigun-na-2017-2023-god (дата звернення: 10.01.2020).

2. Стратегия ВОЗ в области народной медицины 2014-2023 гг. 2013. 72 c. URL: http://www.who.int /medicines/publications/traditional/ trm_strategy14_23/ru/ (дата звернення: 10.01.2020).

3. Xie X. GaoThe idea and approach of the mutual complementarity and integration of TCM and western medicine. J Chendu College TCM. 17 (2). 1994. P. 14-17. [In Chinese].

4. Chen K., Lu A., Chen S., Wei B., Lu W., Mu D., et al. Survey on the developing status of integrative Chinese and western medicine Zhongguo zhong xi yi jie he za zhi. 26 (6). 2006. P. 485-488. [In Chinese].

5. Mao Y, Wu Z, Chen H, Xu Z. Context-based web ontology service for TCM information sharing. In: Proceedings of IEEE international conference on web services (ICWS'05). 2005. P. 699-705.

6. Chen H., Mao Y., Zheng X., Cui M., Feng Y., Deng S., et al. Towards semantic e-Science for traditional Chinese medicine. BMC Bioinform. 8. Suppl. 3. 2007. P. 56. https://doi.org/10.1186/1471-2105-8-S3-S6

7. Оробчук О. Р., Лупенко С. А., Вакуленко Д. В., Сверстюк А. С., Горкуненко А. Б. Integrated Ontobased Information Analytical Environment of Scientific Research, Professional Healing and E-learning of Chinese Image Medicine. Вісник «Інформаційні системи та мережі». Львів: Національний університет «Львівська політехніка», 2017. С. 10-19.

8. Lupenko S., Orobchuk O., Xu M. The Ontology as the Core of Integrated Information Environment of Chinese Image Medicine / eds Hu Z., Petoukhov S., Dychka I., He M. Advances in Computer Science for Engineering and Education II. ICCSEEA 2019. Advances in Intelligent Systems and Computing. Vol 938. 2020. Springer, Cham. P. 471-481. https://doi.org/10.1007/978-3-030-16621-2_44 
Method of development and architecture of integrative ontooriented system for proffesional healing activity «Image therapist» for the chinese image medicine

9. Lupenko S., Orobchuk O., Osukhivska H., Xu M., Pomazkina T. Methods and means of knowledge elicitation in Chinese Image Medicine for achieving the tasks of its ontological modeling: conference proceedings: Ieee 2nd Ukraine Conference on Electrical and Computer Engineering (Lviv, July 2-6, 2019.). Lviv, 2019. P. 885-858. (IEEE UKRCON-2019). https://doi.org/10.1109/UKRCON.2019.8879851

10. Lupenko S., Pasichnyk V., Kunanets N., Orobchuk O., Mingtang Xu. The Axiomatic-Deductive Strategy of Knowledge Organization in Onto-based e-learning Systems for Chinese Image Medicine. Informatics \& Data-Driven Medicine. Proceedings of the 1st International Workshop on Informatics \& Data-Driven Medicine. November 2018. Vol. 2255. P. 126-134.

11. Lupenko S., Orobchuk O., Pomazkina T., Mingtang X. Conceptual, Formal and Software-Information Fundamentals of Ontological Modeling of Chinese Image Medicine as an Element of Integrative Medicine. World Science. June 2018. Vol. 1. № 6 (34). DOI: https://doi.org/10.31435/rsglobal_ws.

12. Orobchuk O. Methodology of development and architecture of ontooriented system of electronic learning of Chinese image medicine on the basis of training management system. Scientific Journal of TNTU 2018. Vol. 92. No. 4. P. 83-90. https://doi.org/10.33108/visnyk_tntu2018.04.083

13. URL: http://www.idef.com/idef5-ontology-description-capture-method/ (дата звернення: 11.01.2020).

14. Палагин А. В. Архитектура онтолого-управляемых компьютерных систем. Кибернетика и системный анализ. 2006. No. 2. P. 111-124. https://doi.org/10.1007/s10559-006-0061-z

15. Державне підприємство «Комітет 3 питань народної і нетрадиційної медицини Міністерства охорони здоров'я України». URL: http://moz.gov.ua/ua/portal/ oth_narmed.html (дата звернення: 12.01.2020).

УДК 004.77

\title{
МЕТОДОЛОГІЯ РОЗРОБКИ ТА АРХІТЕКТУРА ІНТЕГРОВАНОЇ ОНТООРІЄНТОВАНОЇ СИСТЕМИ ПРОФЕСІЙНОЇ ЦІЛИТЕЛЬСЬКОЇ ДІЯЛЬНОСТІ «ІМІДЖ-ТЕРАПЕВТ» ДЛЯ КИТАЙСЬКОЇ ОБРАЗНОЇ МЕДИЦИНИ
}

\section{Олександра Оробчукㅜㅜ І Ігор Катеринюк ${ }^{2}$}

\author{
${ }^{1}$ Тернопільський національний технічний університет імені Івана Пулюя, \\ Тернопіль, Україна \\ ${ }^{2}$ Inlimited, Київ, Украӥна
}

\begin{abstract}
Резюме. Присвячено розробленню прототипу інтегрованої онтоорієнтованої системи професійної иілительської діяльності «Імідж-терапевт». Зважаючи на стан справ у західній (конвенційній) медчцині та опираючись на вже існуючі результати досліджень, обтрунтовано необхідність розроблення такої системи для проведення якісних клінічних та експериментальних досліджень, створення наукової парадигми КОМ, формування сучасних інтелектуалізованих інформаційних ресурсів у сфері КОМ й Інтегративної медицини та реалізації Програми наукових досліджень КОМ. Сформульовано функиіональні вимоги та розроблено узагальнену архітектуру системи «Імідж-терапевт». Комп'ютерні онтології дозволяють побудувати базу декларативних знань, формалізувати терміни та їх логічний взаємозв'язок, забезпечити інтероперабельність. Такі переваги, а також уніфікачія подання різнорідної інформачії, інтеграчія додатків користувача, автоматизація міркувань, управління знаннями, інтелектуальний пошук інформації дуже важливі для становлення наукових напрямків народних видів медицин. Обтрунтовано онтоорієнтованість даної системи, відповідно до етапів онтологічного аналізу методології IDEF5 виокремлено й охарактеризовано компоненти діагностичної та терапевтичної онтологій КОМ, здійснено їх програмну реалізацію 6 середовищі Protégé. Зважаючи на нестандартний, незвичний для західної медицини характер діагностичних і терапевтичних методів КОМ, виділено види діагностичної й терапевтичної інформачії в КОМ, приділено значну увагу розробленню нових моделей і засобів подання образної інформації КОМ. Розроблено прототип онтоорієнтованої системи професійної цілительської діяльності «Іміджтерапевт». Описано ряд сучасних засобів, які обрані для програмної реалізаџї системи: фреймворк для веб-розроблення, системи керування базами даних, фреймворк для розроблення компонентів інтерфейсу та інтерактивності веб-сторінок, щуо забезпечує кросбраузерність й адаптивність.

Ключові слова: онтологія, онтологічне моделювання, китайська образна медицина, інтегроване інформаційно-аналітичне середовище, система професійної ичілительської діяльності «Імідж-терапевт».
\end{abstract}

